\title{
FUTBALLÓRIÁSOK GAZDASÁGI ELEMZÉSE
}

\author{
Bács Bence András
}

\section{Összefoglalás}

A sportgazdaság egyik legmeghatározóbb, Európában pedig hagyományosan a legfontosabb szektora a „futballipar". A milliók számára élményt szolgáltató futballvállalkozások közül mind sportsikerek szempontjából, mind a gazdasági mutatókat figyelembe véve kiemelkedö a Real Madrid és a Manchester United. Kutatásomban a két klub gazdasági elemzésére vállalkoztam az UEFA 2019-es riportja és a Deloitte évente megjelenö, Football Money League cimü jelentése alapján. Az adatok alapján megállapitható, hogy a közvetitési és kereskedelmi bevételek kiemelkedö mértékben meghatározzák a topklubok árbevételét, ilyen módon müködésüket tekintve, amelyek mögött a média és a globalizáció hatása fedezhetó fel. Továbbá a kutatás rávilágit arra, hogy a spanyol bajnokság teljes árbevétele egyenlötlenül, míg az angol bajnokság teljes árbevétele egyenletesebben oszlik meg a csapatok között. A globalizáció a futballóriások számára biztositja a megfelelö piacot elönyük fenntartásához, amennyiben megfelelöen tudják kihasználni az évek során felépitett hírnevüket, márkaértéküket, és nem felejtik el, hogy a sport világában nemcsak a gazdasági, de a sportteljesitmény is meghatározó szerepet tölt be.

Kulcsszavak: sportgazdaság, futballvállalkozások, Real Madrid, Manchester United, gazdasági elemzés

JEL: $Z 29$ 


\title{
ECONOMIC ANALYSIS OF FOOTBALL GIANTS
}

\begin{abstract}
Football industry is one of the most determining sectors and traditionally the most important sector in Europe of sport economics. Among football enterprises Real Madrid and Manchester United are outstanding in the light of both sport and economic successes. In my research I focused on the economic analysis of these two clubs based on the UEFA report published in 2019 and on Deloitte's "Football Money League” reports. Broadcasting and commercial revenues are a major determinant of top club's revenues, so their operation as well which are the effects of the media and globalization. Furthermore the research highlights that revenues are unequally broken down amond participating teams in spanish "La Liga” and more equally in english „Premier League”. Globalization provides the right market for the football giants to sustain their benefits if they can make good use of their reputation and brand value built up over the years and they do not forget that not only economic but also sports performance plays a decisive role in the world of sport.
\end{abstract}

Keywords: sports economics, football enterprises, Real Madrid, Manchester United, economic analysis

JEL: Z29 


\section{Bevezetés}

A sportgazdaság évről évre nagyobb arányban járul hozzá a világgazdasághoz, a sportgazdaság részeként a látványsportok (Bácsné et al., 2019), még inkább szűkítve a labdarúgás, hatalmas érdeklődési szint mellett mozgatja a gazdaság ezen ágazatát. A futballversenyrendszerek évről évre milliók számára nyújtanak szórakozást, és tartják össze városok, régiók, országok és a világ közösségét. Magyarországon egy 2018-as kutatás $(\mathrm{n}=800)$ vizsgálta, hogy melyik a legkedveltebb hazai sportág. A kérdőíves eredmények alapján a sportágak tekintetében megállapítható, hogy még mindig toronymagasan vezet a futball. (Az első helyeken a labdajátékok - labdarúgás, kézi- és vízilabda - és az úszás szerepel, ezeket követik az atlétikai sportágak, majd a kevésbé ismertek/elterjedtek (Bácsné et al., 2018a).

A világ két legmeghatározóbb labdarúgó-bajnoksága az angol Premier League és a spanyol LaLiga, nemcsak versenysport, de gazdasági szempontok alapján is (Bács, 2020). Ahogy a bajnokságok között, úgy a bajnokságon belül is vannak kiemelkedő eredményekkel rendelkező csapatok, futballvállalkozások. Az angol Manchester United és a spanyol Real Madrid hosszú évek óta a legjobb három között szerepel a labdarúgóklubok gazdasági versenyének képzeletbeli dobogóján.

\section{Szakirodalmi áttekintés}

\section{A futballipar jellemzöi}

A többi iparághoz hasonlóan, a futballiparnak is számos saját megkülönböztető jellemzője van:

- Az üzleti siker függ a sport sikerességétől. („A nyereség győzelemmel kezdődik” - mondja Dempsey-Reilly (1998: 89) idézi Bühler, 2007).

- Az eredmény bizonytalansága: a labdarúgás eredményei nem kiszámíthatóak, ami megnehezíti a hosszú távú tervezést.

- Az asszociatív verseny: bármely más iparágban a cégek nyereséget szereznek monopolhelyzetben, míg a labdarúgó üzleti klubok kellenek egymásnak annak érdekében, hogy elóállíthassák a terméket (a tiszta játékot). Egyébként a termék unalmas lenne, és a kereslet egyesek szerint csökkenne (Dempsey-Reilly, 1998; SzymanskiKuypers, 1999 idézi Bühler, 2007).

- A nyereséghez való hozzáállás: minden vállalat célja a profit maximalizálása (Dajnoki-Héder, 2017). A labdarúgóklubok azonban elsősorban sportszervezetekként müködnek (Bácsné, 2015a)b)c). 
- A labdarúgóklubok és rajongóik közötti különleges kapcsolat: a szurkolók magas szintű lojalitást mutatnak, szenvedély és irracionalitás jellemezi őket. Ez más termékek, szolgáltatások fogyasztóitól megkülönbözteti ezt a fogyasztói kört. Lényegében minden a szurkolóktól függ a professzionális labdarúgásban: a kluboknak szurkolókra van szükségük, hogy eladják jegyeiket, a médiának a szurkolókra van szüksége mint előfizetőkre vagy vásárlókra, és a szponzorok a szurkolókból kívánnak ügyfeleket nyerni (Pierpoint, 2000; Conn, 2001; Banks, 2002; Cashmore, 2003; Bühler, 2005b idézi Bühler, 2007; Dajnoki et al., 2018).

A nyilvános működés (Morrow, 1999: 2), a nyilvánosság megnehezíti a labdarúgóklubok müködését, mivel minden döntést vagy hibát nyilvánosan tárgyalnak (Key Note 2002; Grünitz és von Arndt, 2002; WGZ-Bank 2002; Deloitte, 2005 idézi Bühler, 2007).

A sport és különösen az európai labdarúgás gazdasági szerkezetét Andreff és Staudohar (2000) modellezte. A sportüzlet pénzügyi szerkezetének vizsgálata alapján alakították ki az MCMMG-modellt (Medias-Corporations-MerchandisingMarkets-Global). Eszerint a sportszolgáltatások bevételeit a médiához, a gazdasági társasági formához, a merchandising tevékenységhez, a piacokhoz és a globalizációhoz kötik. A labdarúgás 1995 utáni pénzügyi helyzetének magyarázatára Bourg és Gouguet (2012) alkotta meg a SATI-modellt (Sponsors-Actionnaires-TelevisionInternational), amelyben a szponzorokat, a részvényeseket, a televíziót és a nemzetköziesedést jelölik meg a jövedelemtermelés mozgatórugójaként. Bastien (2013) a két korábbi modellt összeolvasztotta SATEMMI modellé (SpectateursActionnaires-Television-Entreprise-Marches-Merchandising-International), amely mindkét korábbi modellváltozat tényezőit tartalmazza. Dima (2015) ezen kutatások összegzéseként megállapítja, hogy az európai futballipar jelenlegi üzleti modellje három fontos jövedelemtermelő tényezőn alapszik:

1. médiajogok - a médiavállalatok által a sportesemények sugárzása érdekében fizetett érték;

2. kereskedelmi bevételek - szponzorálás és egyéb üzleti bevételek (márkamegjelenítés pólón, stadionban, médiában, egyéb marketingtevékenységek, konferenciaszolgáltatások, vendéglátóipar stb.);

3. a mérkőzésnapi bevételek - a jegyértékesítés (beleértve a bérleteket is) és a támogatók költségei a stadionban (promóciós termékek, szolgáltatások) (Dima, 2015): 


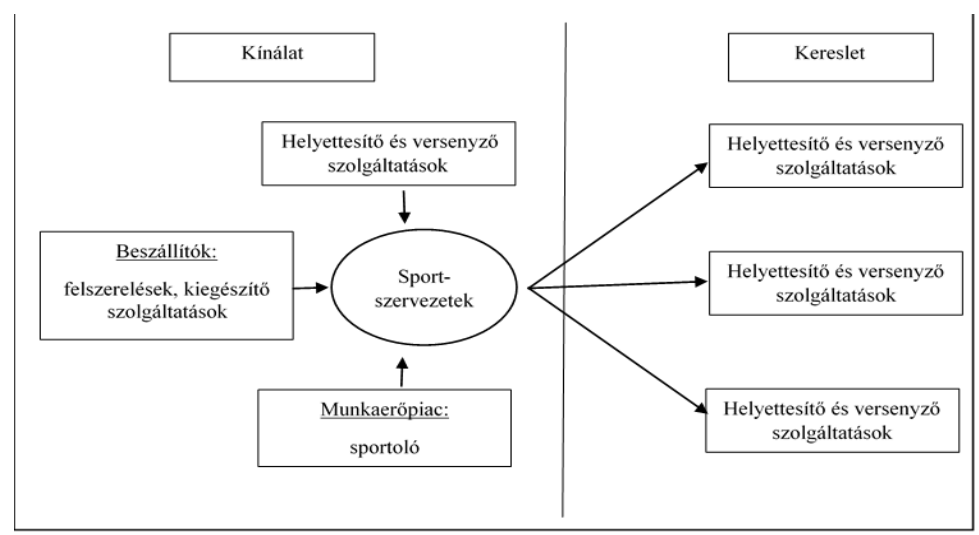

1. ábra: A hivatásos sport modellje

Forrás: Dénes, 2009 idézi Paár 2013

Paár (2013) idézve Dénest (2009) a professzionalista sport modelljét mutatja be. Az előzőekkel összhangban a modellben a sportszolgáltatások keresleti oldalán találhatjuk a fogyasztókat, a médiát és a szponzorokat, vagyis azokat, akiktől a futball bevételei származnak. A kínálati oldal szereplőiként a sportszolgáltatókat és a sportolókat (mint munkaerőt) és a beszállítókat tünteti fel (Bujdosó-Dávid, 2013; Bácsné et al., 2018b).

A fentiek összegzéseként is értelmezhető, hogy András (2003) a hivatásos sport öt piacát azonosítja be: a fogyasztói, a játékos- (Balogh et al., 2019), a közvetítési jogok, a szponzori és a merchandising-piacot.

\section{Anyag és módszer}

Vizsgálatom módszereként a dokumentumelemzést választottam. A klubok elemzését az egyes csapatok beszámolóinak, valamint a Deloitte könyvvizsgáló cég évente kiadott Football Money League riportjának (amely a labdarúgóklubokat árbevétel szempontjából rangsorolja) segítségével állítom össze. Fontos megjegyezni, hogy az UEFA a Club Licensing Benchmarking Report of Financial Year 2017 címü, 2019-ben kiadott jelentésében sokszor ingázik adott (ősz-tavaszi) szezon és üzleti év között, ez nem szerencsés, hiszen mára a klubok többsége az üzleti évét a müködéséhez, azaz a bajnoki szezonhoz igazítja. A húsz topklub árbevételének összehasonlításánál észrevehető, hogy amit az UEFA jelentésében 2017-es üzleti évnek jelez, az a Deloitte 2018-as jelentésében 2016/17-es szezonként szerepel, ugyanakkor az UEFA-jelentés tartalmaz 2017/18-as szezonra vonatkozó információkat is.

A piacvezető klubokat az UEFA-jelentés tízéves időtartamával ellentétben rövidebb távon, a legutóbbi három év időszakában vizsgálom, tehát a 2015/16, 2016/17 
és 2017/18-as szezonokban. A csapatok árbevételét az UEFA-jelentéssel való összehasonlíthatóság kedvéért a 2016/17-es időszakban (UEFA 2017-es üzleti év) vizsgálom. A topklubok és az egyes bajnokságok átlagos csapatainak árbevételének összehasonlítása során az UEFA-jelentésre kell hagyatkozni az átlagos számok esetében, az egyes klubok adatai pedig beszámolóikból és a Deloitte FML-jelentéséből nyerhetőek ki. Az árbevételt a Deloitte-jelentés három, az UEFA-jelentés ezzel szemben öt kategóriába sorolja. Az összehasonlíthatóság érdekében az UEFA-tól kapott és egyéb bevételeket külön soron jelenítem meg, és összegét a teljes éves árbevétel vizsgálata során veszem figyelembe.

\section{Futballóriások}

\section{A Premier League gazdasági királya, a Manchester United}

A Manchester United Football Club Anglia egyik leghíresebb és legsikeresebb labdarúgóklubja. Hússzoros angol bajnok (Premier League, régebben Football League First Division), tizenkétszeres kupagyőztes (FA-kupa), ötször nyerte meg a Ligakupát, háromszor Európa első számú kupasorozatát (BEK, Bajnokok Ligája) és egyszer a KEK-et, az Interkontinentális kupát, az Európai szuperkupát, az Európa Ligát, valamint a klubvilágbajnoki trófeát hódította el (I1).

A klub jogelődjét 1878-ban alapították a vasúti társaság Newton Heath-i depójának csapataként, azonban a klub, amelyet ma ismerünk, az 1990-es években indult valódi útjára, a legendás Alex Ferguson irányításával, amikor 12 év alatt 9-szer nyerte meg az angol bajnokságot.

1999-ben a Manchester United volt az első csapat, amely ugyanabban a szezonban megnyerte az UEFA Bajnokok Ligáját, az angol bajnokságot és az angol kupát. (Ezután lovaggá ütötték a legendás edzőt, Alex Fergusont.) A klub 1991 óta részvénytársaság (Public Limited Company) formájában működik. 2005-ben Malcolm Glazer megvette a klub részvényeinek nagy részét. Noha a vételár jelentős része kölcsön volt, a klub hamar talpra állt, 2007-ben átigazolásokra körülbelül 100 millió eurót (25 milliárd forint) költött (I2).

A klub 2012-ben lépett tőzsdére, az értékesítésre felajánlott értékpapírok a klub értékének 10\%-át testesítették meg, Azonban a klubot még 2005-ben megvásárló Glazer család az IPO-t követően is a szavazati jogok mintegy 99\%-át birtokolja (Bácsné, 2016b), miután a tulajdonukban lévő, B-sorozatú részvények darabonként 10 szavazati jogot képviselnek. Ezzel szemben kibocsátás során értékesített A-sorozatú papírokhoz csupán egy szavazati jog társul (I3). 
A klub első számú (mez)szponzora a vizsgált három idényben a Chevrolet volt, az amerikai autógyártó, a General Motors tagja. A globális szinten tevékenykedő autóipari óriás választása nem véletlen, hiszen a Manchester rendkívüli népszerűségnek örvend világszerte, közösségi médiákon: a Facebookon, Instagramon és Twitteren a harmadik legkövetettebb futballcsapat a világon.

Az átlag nézőszám az Old Traffordon, a Manchester United otthonában, a 2017/18-as szezonban 75102 fö, ami közel kétszerese az angliai átlagos nézőszámnak. A hazai bajnoki mérkőzésekre 1424544 fó látogatott ki az év folyamán a stadionba, ami az angliai össznézőszám (14 557667 fö) 9,7\%-a (UEFA, 2019).

Az 1. táblázat megmutatja a Manchester United árbevételét és annak megoszlását (millió euróban kifejezve) a 2016, 2017 és 2018-as időszakokban.

1. táblázat: A Manchester United árbevétele és annak megoszlása a 2016 és 2018 közötti időszakban

\begin{tabular}{|c|c|c|c|}
\hline \multirow{2}{*}{$\begin{array}{l}\text { A Deloitte Football Money League-helyezése } \\
\text { millió € }\end{array}$} & $1 \#$ & $1 \#$ & 3\# \\
\hline & $2015 / 16$ & $2016 / 17$ & $2017 / 18$ \\
\hline Árbevétel összesen & 689 & 676,3 & 666 \\
\hline \multirow{2}{*}{$\begin{array}{l}\text { Jegy- és helyszíni bevételek } \\
\text { Bevételkategória/Árbevétel }\end{array}$} & 137,5 & 125,2 & 119,5 \\
\hline & $20 \%$ & $19 \%$ & $18 \%$ \\
\hline Változás & & $-8,95 \%$ & $-4,55 \%$ \\
\hline \multirow{3}{*}{$\begin{array}{l}\text { Közvetítési bevételek } \\
\text { Közvetítési bevételek / Árbevétel } \\
\text { Változás }\end{array}$} & 187,7 & 225,9 & 230,4 \\
\hline & $27 \%$ & $33 \%$ & $35 \%$ \\
\hline & & $20,35 \%$ & $1,99 \%$ \\
\hline \multirow{3}{*}{$\begin{array}{l}\text { Kereskedelmi és szponzorációs bevételek } \\
\text { Kereskedelmi bevételek / Árbevétel } \\
\text { Változás }\end{array}$} & 363,8 & 325,2 & 316,1 \\
\hline & $53 \%$ & $48 \%$ & $47 \%$ \\
\hline & & $-10,61 \%$ & $-2,80 \%$ \\
\hline
\end{tabular}

Forrás: Saját szerkesztés a Deloitte Football Money League 2017, 2018 és 2019-es riportjai alapján

Annak ellenére, hogy a klub bevételei (a közvetítési bevételek kivételével) folyamatosan csökkentek a vizsgált időszakban, a United élen tudott maradni az árbevételért folytatott küzdelemben. A klub számára esszenciálisnak bizonyult az Európa Ligagyőzelemmel járó 44,5 millió euró, amivel a Real Madrid és a Barcelona előtt tudott maradni a képzeletbeli árbevétel-dobogón. (Az összeg - 44,5m € - több mint négyszerese a 2011/12-es győztes Atletico által kapott összegnek, ami mutatja az UEFA szándékát, hogy az általa rendezett európai kupák mindegyike biztosítsa a megfelelő pénzügyi jutalmazást - Deloitte, 2018.) 
A Manchester United árbevétele a 2016/17-es szezonban 676,3 millió euró, ami a teljes Premier League bevételének több mint 12\%-át jelenti. A húszcsapatos bajnokságot nézve egy átlagos Premier League-csapatnál a Manchester United mint a gazdaságilag legerősebb angol klub több mint 390 (409,3 (eltérés) - 18,9 (UEFApénzdíj és egyéb bevétel)) millió euróval nagyobb árbevételről számolt be 2017-ben, és árbevétele arányában több mint kétszerese az átlagos klubokénak (2. táblázat). A bevételek megoszlásának vizsgálata során látható, hogy a klub bevételszerkezete eltér a ligaátlagtól. Jegy- és bérletbevételei (19\%), valamint kereskedelmi bevételei (48\%) arányaiban nagyobb részét fedik az árbevételnek.

\section{2. táblázat: A Manchester United árbevételének összehasonlítása az átlagos} Premier League csapatokéval a 2016/17-es szezonban

\begin{tabular}{|l|c|c|c|}
\cline { 2 - 4 } \multicolumn{1}{c|}{$2016 / 17-$ millió $€$} & $\begin{array}{c}\text { Manches- } \\
\text { ter United }\end{array}$ & $\begin{array}{c}\text { Átlag Pre- } \\
\text { mier League- } \\
\text { csapat }\end{array}$ & Eltérés \\
\hline Árbevétel összesen & 676,3 & 267 & 409,3 \\
\hline Jegy- és helyszíni bevételek & 125,2 & 34,8 & 90,4 \\
\hline Bevételkategória/Árbevétel & $19 \%$ & $13 \%$ & $5 \%$ \\
\hline Közvetítési bevételek & 225,9 & 145,5 & 80,4 \\
\cline { 2 - 4 } Közvetítési bevételek / Árbevétel & $33 \%$ & $54 \%$ & $-21 \%$ \\
\hline Kereskedelmi és szponzorációs bevételek & 325,2 & 67,8 & 257,4 \\
\cline { 2 - 4 } Kereskedelmi bevételek / Árbevétel & $48 \%$ & $25 \%$ & $23 \%$ \\
\hline UEFA-pénzdíj és egyéb bevétel & 0 & 18,9 & $-18,9$ \\
\hline
\end{tabular}

Forrás: Saját szerkesztés a Deloitte Football Money League 2018 és az UEFA Club Licensing Benchmarking Report of Financial Year 2017 2019-es riportjai alapján

Az egyesületi és magántulajdonban lévő klubok összehasonlítása érdekében a Manchester Unitedot további mutatók tekintetében is vizsgáltam, a bérek árbevételhez viszonyított aránya és az eszközök értékének tekintetében. 
3. táblázat: A Manchester United és egy átlag angol csapat bér/árbevétel aránya, valamint összes eszköze a 2016/17-es idényben

\begin{tabular}{|l|c|c|}
\hline $2016 / 17-$ millió $€$ & Manchester United & Premier League Átlag \\
\hline Bérek/Árbevétel & $45 \%$ & $56 \%$ \\
\hline Összes eszköz értéke & 1746 & 489 \\
\hline
\end{tabular}

Forrás: Saját szerkesztés az UEFA Club Licensing Benchmarking Report of

Financial Year 2017 2019-es és a Manchester United 2016/17-es

szezonra vonatkozó éves beszámolója alapján

Ahogy az a 3. táblázatban megfigyelhető, a United bér/árbevétel aránya a 2017-es évben 45\%-on állt, ami alacsonyabb, mint az angol kluboknál általánosan, ugyanakkor a kisebb arányszám mögött az óriási árbevétel miatt nagyobb összegek bújnak el, mint ligán belüli versenytársainál. Összes eszközének értéke meghaladja az 1,7 milliárd eurót, a liga átlagának több mint háromszorosa a United vagyonának értéke.

\section{A királyi gárda, a Real Madrid}

A Real Madrid 1902-es alapításával már közel 115 éves múltra tekint vissza. A 20002001-es idényben a FIFA (Fedérátion Internacionale de Football Association) a 20. század legjobb focicsapatának nevezi a klubot, amelynek meghatározó a szerepe a világfutballban. Ez nem meglepő, hiszen a csapat 33-szoros spanyol bajnok, 19-szeres spanyol kupagyőztes, és 13-szoros UEFA Bajnokok Ligája-győztes (Bács, 2016).

A világ futballvállalkozásainak nagy részével ellentétben a Real Madrid nem társasági formában, hanem egyesületként müködik. Egyesületi tagjainak száma 2015ben 91846 fö. Ebből 66671 felnőtt, 19797 gyermek és 537865 évnél idősebb, vagy több mint 50 éve tag. Világszerte 2311 szurkolói klubbal rendelkezik, ebből 2 158 Spanyolországban, 153 pedig a világ különböző pontjain van (Bácsné, 2016a).

A klub föszponzora az Emirates, a Közel-Keleti régió legnagyobb és Dubaj hivatalos légitársasága, egyben a futball egyik legmeghatározóbb szponzora. Mind az öt nagy ligában megjelenik amellett, hogy FIFA-rendezvényeket is szponzorált a 2015ös korrupciós ügyükig a FIFA-val. (A 2022-es világbajnokság Katarban történő megrendezésének tervéhez kapcsolható az ügy.) Az Emirates globális tevékenységet végez, igyekszik az európai futballt saját népszerűsítésére használni (Deloitte, 2018).

A „blanco”-knál jobb alternatívát a klub történelmét és (globális) szurkolótáborát figyelembe véve nem is találhattak volna. A globális támogatottság alátámasztása ér- 
dekében a 2019-es közösségimédia-adatokra támaszkodva a Real Madridnál egy futballcsapat sem rendelkezik több követővel. (Facebookon több mint 109 millióan, Instagramon több mint 67 millióan és Twitteren több mint 31 millióan követik a klub mindennapjait.)

Az átlag nézőszám a Santiago Bernabeu stadionban, a Real Madrid otthonában a 2017/18-as szezonban 66337 fö, ami több mint kétszerese a spanyol átlagos nézőszámnak. A hazai bajnoki mérkőzésekre 1257059 fö látogatott ki az év folyamán a stadionba, ami a spanyol össznézőszám (10 285878 fö) 12,2\%-a.

A 4. táblázat megmutatja a Real Madrid árbevételét és annak megoszlását millió euróban kifejezve.

\section{4. táblázat: A Real Madrid árbevétele és annak megoszlása} a 2016 és 2018 közötti időszakban

\begin{tabular}{l|c|c|c|}
\cline { 2 - 4 } \multirow{2}{*}{$\begin{array}{l}\text { A Deloitte Football Money League-helyezése } \\
\text { millió } €\end{array}$} & $3 \#$ & $2 \#$ & $1 \#$ \\
\cline { 2 - 4 } & $2015 / 16$ & $2016 / 17$ & $2017 / 18$ \\
\hline Árbevétel összesen & $\mathbf{6 2 0 , 1}$ & $\mathbf{6 7 4 , 6}$ & 750,9 \\
\hline Jegy- és helyszíni bevételek & 129 & 136,4 & 143,4 \\
\cline { 2 - 4 } $\begin{array}{l}\text { Bevételkategória/Árbevétel } \\
\text { Változás }\end{array}$ & $21 \%$ & $20 \%$ & $19 \%$ \\
\hline Közvetítési bevételek & 227,7 & $5,74 \%$ & $5,13 \%$ \\
\cline { 2 - 4 } $\begin{array}{l}\text { Közvetítési bevételek / Árbevétel } \\
\text { Változás }\end{array}$ & $37 \%$ & $35 \%$ & $33 \%$ \\
\hline Kereskedelmi és szponzorációs bevételek & 263,4 & 301,4 & 356,3 \\
\cline { 2 - 4 } $\begin{array}{l}\text { Kereskedelmi bevételek / Árbevétel } \\
\text { Változás }\end{array}$ & $42 \%$ & $45 \%$ & $47 \%$ \\
\cline { 2 - 4 } & & $14,43 \%$ & $18,18 \%$ \\
\hline
\end{tabular}

Forrás: Saját szerkesztés a Deloitte Football Money League 2017, 2018 és 2019-es riportjai alapján

A királyi gárda árbevétele évről évre szignifikáns növekedést mutat, ami alátámasztja a klub gazdasági és működési modelljét, valamint az öt év alatt elért négy Bajnokok Ligája-győzelem $(2014,2016,2017,2018)$ is nagymértékben hozzájárul a klub gazdasági sikerességéhez.

Az 5. táblázatból kiderül, hogy Real Madrid árbevétele a vizsgált 2016/17-es időszakban 674,6 millió euró, a teljes spanyol liga árbevételének több mint 23\%-a. Feltételezve, hogy a Barcelona is hasonló mértékben részesül a bevételekből, azt jelenti, 
hogy a két klub a teljes spanyol élvonal árbevételének közel 50\%-át tudhatja magáénak, ami a húszcsapatos bajnokságot tekintve rávilágít mennyire egyenlőtlen a csapatok között az árbevétel megosztása.

5. táblázat: A Real Madrid árbevételének összehasonlítása az átlagos LaLiga-csapatokéval a 2016/17-es szezonban

\begin{tabular}{|l|c|c|c|}
\cline { 2 - 4 } \multicolumn{1}{c|}{$2016 / 17-$ millió $€$} & $\begin{array}{c}\text { Real } \\
\text { Madrid }\end{array}$ & $\begin{array}{c}\text { Átlag LaLiga- } \\
\text { csapat }\end{array}$ & Eltérés \\
\hline Árbevétel összesen & 674,6 & 144,95 & 529,65 \\
\hline Jegy- és helyszíni bevételek & 136,4 & 24,3 & 112,1 \\
\cline { 2 - 4 } Bevételkategória/Árbevétel & $20 \%$ & $17 \%$ & $3 \%$ \\
\hline Közvetítési bevételek & 236,8 & 62,5 & 174,3 \\
\cline { 2 - 4 } Közvetítési bevételek / Árbevétel & $35 \%$ & $43 \%$ & $-8 \%$ \\
\hline Kereskedelmi és szponzorációs bevételek & 301,4 & 35 & 266,4 \\
\hline Kereskedelmi bevételek / Árbevétel & $45 \%$ & $24 \%$ & $21 \%$ \\
\hline UEFA-pénzdíj és egyéb bevétel & 0 & 23,15 & $-23,15$ \\
\hline
\end{tabular}

Forrás: Saját szerkesztés a Deloitte Football Money League 2018 és az UEFA Club Licensing Benchmarking Report of Financial Year 2017 2019-es riportjai alapján

A Real bevétele több mint 500 millió euróval magasabb, több mint négyszerese az átlagos klubok bevételének. Ez óriási különbség, amely az összárbevétel kategóriában jelentkezik. Árbevételének megoszlása tükrözi a klub kereskedelmi és szponzorációs potenciálját. A kereskedelmi bevételek összege önmagában kétszerese az átlagos csapatok éves árbevételének. Jegy- és helyszíni bevételei 20\%, közvetítési bevételei 35\% és kereskedelmi bevételei 45\%-ban járulnak hozzá árbevételéhez (5. táblázat).

A Real Madrid esetében a bér/árbevétel aránya (60\%) közeli a liga átlagos, 58\%os arányához, ugyanakkor a klub abszolút értékben sokkal nagyobb összegeket költ játékosai és a stáb bérezésére, hiszen árbevétele a teljes liga bevételének 23\%-át adja.

6. táblázat: A Real Madrid és egy átlag spanyol csapat bér/árbevétel aránya, valamint összes eszköze a 2016/17-es idényben

\begin{tabular}{|l|c|c|}
\hline $2016 / 17-$ millió $€$ & Real Madrid & LaLiga Átlag \\
\hline Bérek/Árbevétel & $60 \%$ & $58 \%$ \\
\hline Összes eszköz értéke & 1075 & 240 \\
\hline
\end{tabular}

Forrás: Saját szerkesztés UEFA Club Licensing Benchmarking Report of Financial Year 2017 2019-es és a Real Madrid 2016/17-es szezonra vonatkozó éves beszámolója alapján 
A Madrid összes eszközének értéke meghaladja az 1 milliárd eurót, ezzel a ligában szereplő klubok átlagos vagyonának több mint négyszeresét birtokolják a blancók.

\section{Óriások csatája, a Manchester United és a Real Madrid összehasonlítása}

A számok nem hazudnak, a legjobb csapatok igen nagy százalékban részesednek hazai bajnokságuk bevételeiből, azonban a Manchester United annak ellenére, hogy jócskán kiemelkedik az angol közegből, arányaiban nem telepszik rá az angol futballra.

A 7. táblázatban szereplő arányszámok rámutatnak, hogy az angol bajnokság bevételeloszlása egyenletesebb, mint a spanyolé. A kutatás alapján ez a közvetítési bevételek egyenletes elosztásának köszönhető, hiszen a jegy- és kereskedelmi bevételek szempontjából a vizsgált klubok a liga összes bevételének igen nagy szeletét tudhatják magukénak.

A klubok további vizsgálata során továbbá felfedeztem, hogy összes eszközük értéke a bajnokság átlagának legalább háromszorosa, amihez évről évre nagyobb mértékben járul hozzá a játékosok könyv szerinti értéke.

7. táblázat: A kiemelt csapatok árbevételei és azok mértéke hazai bajnokságaikon belül 2017-ben

\begin{tabular}{|l|r|r|}
\cline { 2 - 3 } \multicolumn{1}{l|}{$2016 / 17$ - millió $€$} & Manchester United & Real Madrid \\
\hline Árbevétel & 676 & 675 \\
\hline Csapat/liga árbevétel aránya & $13 \%$ & $23 \%$ \\
\hline Közvetítési bevétel & 225,9 & 236,8 \\
\hline Csapatlliga árbevétel kat. aránya & $8 \%$ & $19 \%$ \\
\hline Jegy- és bérletbevétel & 125,2 & 136,4 \\
\hline Csapat/liga árbevétel kat. aránya & $18 \%$ & $28 \%$ \\
\hline Kereskedelmi bevétel & 325 & 301 \\
\hline Csapat/liga árbevétel kat. aránya & $24 \%$ & $43 \%$ \\
\hline
\end{tabular}

Forrás: Saját szerkesztés a Deloitte Football Money League 2018 és az UEFA Club Licensing Benchmarking Report of Financial Year 2017 2019-es riportjai alapján

\section{Összefoglalás}

A „futballipar” két - nemcsak sporteredményességi, de gazdasági vonatkozásban is vezető szerepet betöltő klubját, a Manchester Unitedet és a Real Madridot vizsgáltam gazdasági szempontok alapján, amihez adatokat az UEFA 2019-es riportja és a Deloitte Football Money League-jelentései szolgáltatták. 
Az adatok alapján meghatározható, hogy a közvetítési és kereskedelmi bevételek kiemelkedő mértékben meghatározzák a topklubok árbevételét, ami mögött a média és a globalizáció hatása fedezhető fel. A kutatás rávilágít, hogy a spanyol bajnokság teljes árbevétele egyenlőtlenül, míg az angol bajnokság teljes árbevétele egyenletesebben oszlik meg a csapatok között (a Manchester United a liga teljes árbevételének 13\%-át adja, a Real Madrid bajnokságának 23\%-át adja)

A futballóriások bérezésének aránya az árbevételhez viszonyítva nem tér el nagyban a ligák átlagától, ugyanakkor abszolút értekben meghaladja a versenytársaikét. Vagyonukat vizsgálva pedig megállapítható, hogy a nemzeti bajnokságaikban szereplő klubok vagyonának többszörösével rendelkeznek, aminek egyre meghatározóbb részét képzik a játékosjogok.

A globalizáció a futballóriások számára biztosítja a megfelelő piacot előnyük fenntartásához, amennyiben megfelelően tudják kihasználni az évek során felépített hírnevüket, márkaértéküket és nem felejtik el, hogy a sport világában nemcsak a gazdasági, de a sportteljesítmény is meghatározó szerepet tölt be. (Ahogy a United-nél meg lehetett figyelni, az utóbbi évek sporteredménytelensége bevételeik csökkenéséhez vezetett, ám a klub még így is fenn tudta tartani a topcsapatok között is kiemelkedő árbevétel-termelését.)

\section{Köszönetnyilvánítás}

A publikáció elkészítését az EFOP-3.6.2-16-2017-00003 számú projekt támogatta. A projekt az Európai Unió támogatásával, az Európai Szociális Alap társfinanszírozásával valósult meg.

\section{Hivatkozott források}

[1.] András K. (2003): Üzleti elemek a sportban a labdarúgás példáján. [PhDértekezés]. Forrás:

[2.] http://phd.lib.uni-corvinus.hu/150/1/andras_krisztina.pdf

[3.] Andreff, W. - Staudohar, P. D. (2000): The evolving European model of professional sports finance, Journal of Sports Economics, Vol. 1, No. 3, 257-276. o. DOI: $10.1177 / 152700250000100304$

[4.] Bácsné Bába É. (2015a): Szervezeti változások sikeres sportvállalkozások esetében. Taylor: Gazdálkodás- és Szervezéstudományi Folyóirat: A Virtuális Intézet Közép-Európa Kutatására Közleményei, 7. évf. 3-4. sz. 286294 o. 
[5.] Bácsné Bába É. (2015b): Sportszervezetek működési kereteinek változása. Közép-Európai Közlemények, 8. évf. 28. sz. 151-161. o.

[6.] Bácsné Bába É. (2015c): Examination of the organizational frameworks of sports enterprises in the light of good german practices. Apstract - applied studies in agribusiness and commerce. Vol. 9. No. 1-2. 41-46. p. DOI: 10.19041/apstract/2015/1-2/8

[7.] Bácsné Bába É. (2016a): Szervezeti struktúra jellemzői spanyol labdarúgó kluboknál. Müszaki és Menedzsment Tudományi Közlemények, 1. évf. 1. sz. 1-11. o. DOI: 10.21791/ijems.2016.1.2.

[8.] Bácsné Bába É. (2016b): Futballvállalkozások lehetséges szervezeti formái nemzetközi jó gyakorlatok alapján - esettanulmány a Manchester United FC-ról (Az angol példa). TAYLOR: Gazdálkodás- és Szervezéstudományi Folyóirat: A Virtuális Intézet Közép-Európa Kutatására Közleményei: 2. évf. 23. sz. 95-102. o.

[9.] Bácsné Bába É. - Fenyves V. - Szabados Gy. - Pető K. - Bács Z. - Dajnoki K. (2018a): Sport Involvement Analysis in Hungary, in the North Great Plain Region. Sustainability, Vol. 10. No. 5. DOI:10.3390/su10051629

[10.] Bácsné Bába É. - Balogh, R. - Bács, Z. - Fenyves, V. - Dajnoki, K. (2018b): Sportszolgáltatások keresleti, kínálati oldalának elemzési lehetőségei. Studia Mundi - Economica, 5. évf. 3. sz. 19-33.

DOI: 10.18531/Studia.Mundi.2018.05.03.19-33

[11.] Bácsné Bába É. - Fenyves V. - Szabados Gy. - Dajnoki K. - Müller A Bács Z. (2019): A sportágazat nemzetgazdasági jelentőségének vizsgálata beszámoló adatok alapján 2014-2016-os időszakban. Jelenkori Társadalmi És Gazdasági Folyamatok, 13. évf. 3-4. sz. 93-103. o.

[12.] Bács B. (2016): A Real Madrid gazdasági sikerességének elemzése. [Szakdolgozat]. Debreceni Egyetem, 2016.

[13.] Balogh, R. - Dajnoki, K. - Bácsné, Bába É. (2019): Miért beteg a magyar futball még mindig? - A magyar labdarúgás játékos piacának jellemzése. Jelenkori Társadalmi és Gazdasági Folyamatok, 13. évf. 3-4. sz. 105-117. o.

[14.] Bühler, A. W. (2007): Football as an international business - Anglo-German comparasion. European Journal of Sport and Sociaty, Vol. 8. No. 1. 25-41. p.

[15.] Bujdosó Z. - Dávid L. (2013): Extreme sports and other activities in tourism with special regard to the Mátra Mountain. Journal of Physical Education and Sport, Vol. 13. No. 1. 39-45. p.

[16.] Dajnoki K. - Héder M. (2017): „Új szelek fújnak” - a HR válasza a globalizáció és a változás kihívásaira. Hadtudomány, 27. évf. E-szám 84-93. o. Forrás: http://real.mtak.hu/72149/ 
[17.] Dajnoki K. - Szabados Gy. - Bácsné Bába É. (2018): A Case Study on Human Resource Management Practice of a Sport Organization. International Journal of Engineering And Management Sciences / Müszaki és Menedzsment Tudományi Közlemények, Vol. 3. No. 4. 410-425 p. DOI: 10.21791/ijems.2018.4.34.

[18.] Deloitte (2017): Football Money League, Sports Business Group

[19.] Deloitte (2018): Football Money League, Sports Business Group

[20.] Deloitte (2019): Football Money League, Sports Business Group

[21.] Dima T. (2015): The Business Model of European Football Club Competitions. Procedia Economics and Finance, Vol. 23. 1245-1252. p. DOI: 10.1016/s2212-5671(15)00562-6

[22.] Manchester United (2018): FORM 20-F, Annual report of 2016/17 season.

[23.] Paár D. (2013): A magyar háztartások sportfogyasztásának gazdasági szempontú vizsgálata. [PhD-értekezés]. Nyugat-magyarországi Egyetem Közgazdaságtudományi Kar Széchenyi István Gazdálkodás- és Szervezéstudományok Doktori Iskola, Sopron, 2013. Forrás: http://doktori.uni-sopron.hu/405/

[24.] Real Madrid (2018): Management Report and Financial Statements 20162017

[25.] UEFA „Club Licensing Benchmarking Report of Financial Year 2017” (2019)

[I1] https://www.manutd.com/

[I2] https://hu.wikipedia.org/wiki/Manchester_United_FC

[I3] https://www.portfolio.hu/vallalatok/szaguld-a-manchesterunited.178680.html

\section{Szerző:}

Bács Bence András

PhD-hallgató

Ihrig Károly Gazdálkodás- és Szervezéstudományok Doktori Iskola bacs.bence.andras@econ.unideb.hu 